\title{
8 So many more
}

\begin{abstract}
Most of the children who had left the orphanage before $17^{\text {th }}$ March 1943 were deported. Karel van Santen was caught with his brother Philip in the razzias in Amsterdam in February 1941. They were deported to Buchenwald, Mauthausen, and Schloss Hartheim. The life of Barend Bora Kool illustrates the social circumstances which brought many children into orphanage care: large extended families, poverty, death of a parent, poverty, multiple marriages. One boy was caught by the Germans while living in hiding in Belgium, another in France. The family of Sally Montezinos illustrates how terribly effective the Holocaust was in the Netherlands. The entire family of 20 people, living in various places in the country, was caught and murdered. Even the memory of their existence as a family was almost lost.
\end{abstract}

Keywords: Razzias, Amsterdam, February Strike, Camp Schoorl, deportation, Buchenwald, Mauthausen, Schloss Hartheim, T4, Kazerne Dossin, Pithiviers

The previous chapter focused on the 59 people who were removed from the orphanage on $17^{\text {th }}$ March 1943 . Some of the 62 children who left the orphanage before $17^{\text {th }}$ March 1943, and who did not survive the war, also found a place in Chapter 7 , but so many more could not be included. The stories which follow are dedicated to their memory.

Chapter 8.1 is about Karel van Santen, who was, to the best of my knowledge, the first of the (erstwhile, since 1929) inhabitants of the Leiden orphanage to perish in the Holocaust. He and his brother Philip were deported in February 1941, first to Buchenwald, then to Mauthausen, just nine months into the German occupation of the Netherlands.

Little is known about Barend Bora Kool (Ch. 8.2), but his extended family illustrates the social circumstances which brought many children to the orphanage in the first place, although most of them still had one or even two living parents.

Jacques Witteboon was deported from France (Ch. 8.3), where conditions for Jews were complicated by the division between occupied France and the area controlled by the Vichy government (see also Chs. 9.7 and 9.8).

Focke, Jaap W., Machseh Lajesoumim: A Jewish Orphanage in the City of Leiden, 1890-1943. Amsterdam, Amsterdam University Press 2021 DOI: 10.5117/9789463726955_CHo8 


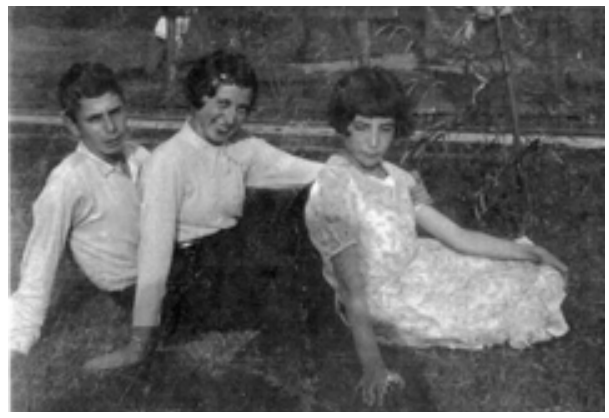

Figure 8.1: Karel, Jenny and Esje (Els) van Santen, c. 1927 , when all three were resident in the orphanage.

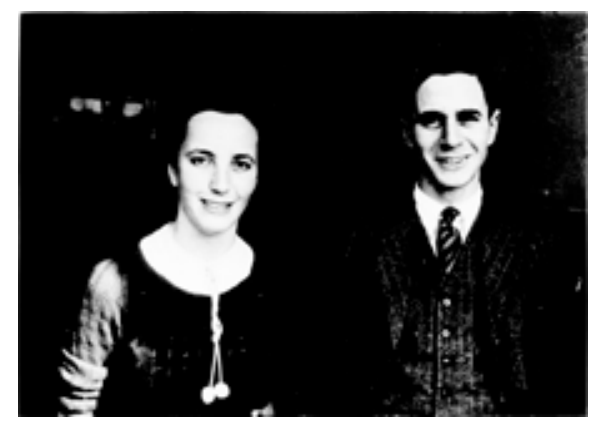

Figure 8.2: Els and Karel, c. 1938.

Alexander Lipschits was caught in Brussels and deported from Mechelen (Ch. 8.4). Compared to the Netherlands, circumstances in Belgium were different: it was under authority of the German army, the king had stayed behind, and there was initially no central registration telling the Germans who was Jewish.

Chapter 8.5 is about the family of Sally Montezinos, who is one of those who "carry the story" throughout this book. Most of the children in the orphanage, including Sally, came from families which were not in a strong social position. They generally had no protection against the fanatic and tenacious nature of the persecution of Jews. It did not matter where they were, distributed over the country, in all sorts of homes and institutions. Their children, parents, siblings, grandparents, nephews, and cousins were all caught, deported, murdered. It is disconcerting to observe how close the Nazis came to eradicating even the memory that they ever existed.

\subsection{Karel van Santen}

Three of the children van Santen from The Hague lived in the Leiden orphanage: Jenny (1914) for almost eight years, Karel (1918), ten years or more, and Esther ("Els", 1920) for more than sixteen years. From December 1926, when Karel was the last to arrive, to April 1932, when Jenny was the first to leave, they were all three living in the orphanage in Leiden (Figs. 8.1 and 8.2). Karel was drafted for military service in 1937; he had become eighteen on $16^{\text {th }}$ September the year before; at that time boys were initially drafted for half a year, so he probably did not actually live in the orphanage for the whole of 1937. He was called up again when Holland mobilized in August 1939, together with Herman Stofkooper (Ch. 9.7). Even if he was not resident, he certainly appeared frequently in the orphanage where practically everybody knew him. He was only officially written out of the Leiden registry on $2^{\text {nd }}$ July 1940 when he was 21. 


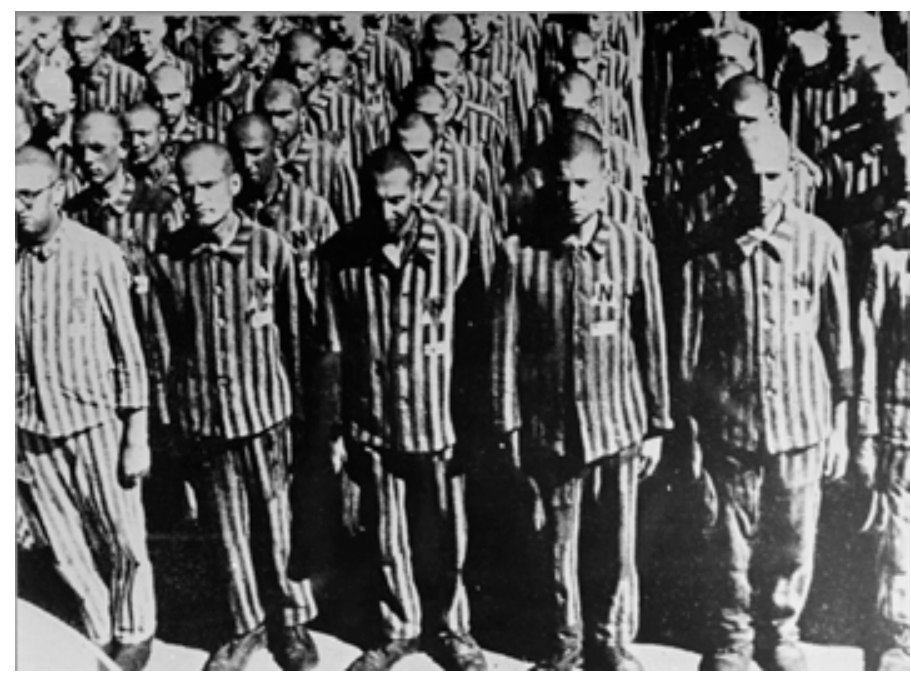

Figure 8.3.: Dutch Jews from the very fi rst mass deportation from Holland, on the day of their arrival in KL Buchenwald: $28^{\text {th }}$ February 1941. The $\mathrm{N}$ on their jacket stands for Niederlände. Karel and Philip van Santen were both part of this group. Photo courtesy Gedenkstätte Buchenwald and many other sources.

Karel and his brother Philip ${ }^{1}$ happened to visit a friend in Amsterdam ${ }^{2}$ on $22^{\text {nd }}$ February 1941, when the Germans took revenge for the street fighting in Amsterdam's Jewish Quarter the week before. Both boys were caught during the two-day razzia; in total some 300 men were arrested on $22^{\text {nd }}$ and $23^{\text {rd }}$ February and brought to Camp Schoorl. On $27^{\text {th }}$ February 1941, arguably in response to the February Strike (Ch. 6.3), a train took $389^{4}$ of them from Alkmaar (the nearest railway station) to Weimar in Germany, from where they were force-marched to Buchenwald, the same camp where Lotte Adler's father had been killed in 1938. It was the first mass transport of Jews from the Netherlands, just nine months after the invasion, and one and a half years before systematic mass deportations to Auschwitz started from Westerbork. The context of these early (February 1941) deportations from Holland is often said to be different from the later (July 1942) deportations from Westerbork, Mechelen (Belgium) and Drancy (France). In early 1941 the plans for genocide on

1 His full name was Philip Karel. He was born in Amsterdam on $6^{\text {th }}$ November 1915. He never lived in the orphanage.

2 Testimony of Esther van Santen, as recorded by her son.

3 The list of arrested people had to be reconstructed by the Red Cross based on incomplete data.

4 The group also changed slightly as men who were arrested in other places were added to the transports, while others from the original group were not included in the transport to Buchenwald. Thus, comparing the number of people in each group as transported from Amsterdam to Schoorl, Buchenwald and, eventually, Mauthausen, is not always exact. 

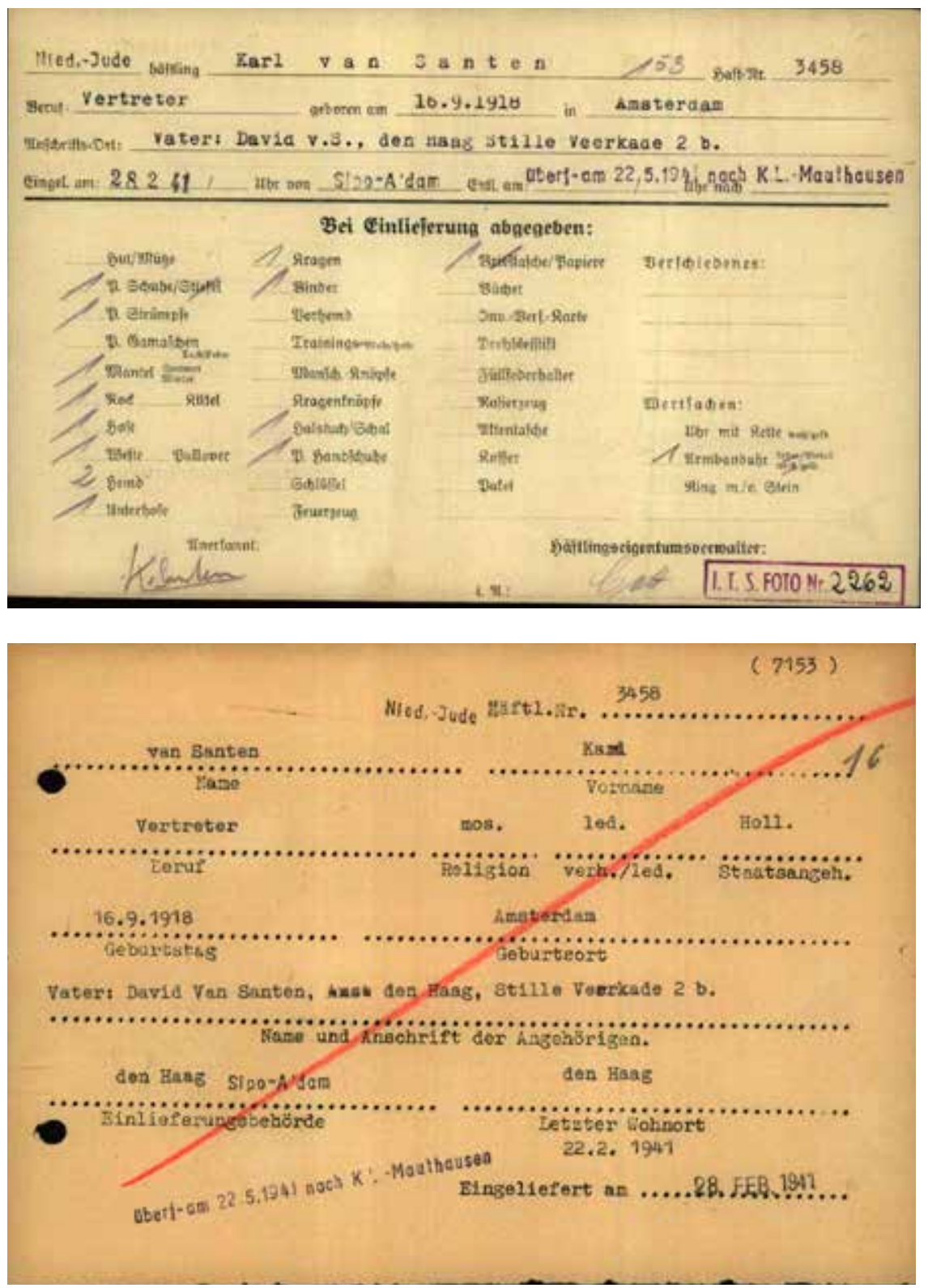

Figure 8.4: The meticulous administration of this stage of the Holocaust, before it developed into the "Final Solution", is astounding. Above: Karel's Buchenwald registration card, duly recording the date of his arrest, arrival in Buchenwald, and his transfer to Mauthausen, as well as itemizing each piece of clothing taken from him, including his wristwatch. Below: another Buchenwald registration card, with Häftling (prisoner) number, Sipo Amsterdam having made the arrest (not The Hague as could be suggested by the typing), arrival date in Buchenwald (28 ${ }^{\text {th }}$ February 1941) and further deportation to Mauthausen on $22^{\text {nd }}$ May 1941. Both documents courtesy ITS Arolsen. 
a massive scale had not yet crystallized. But the purpose of the deportations was the same: the deportees, randomly picked from the streets of Amsterdam and other cities, only because they were Jews, were meant to die as soon as possible. If anything, the deportations of February 1941 and the deliberately arranged murder of all deportees illustrate how fanatical, deadly and efficient the persecution of Jews was in the Netherlands.

The deportations took place in a very orderly and efficient manner. Upon arrival in Buchenwald the men were registered and even photographed (Fig. 8.3) and given striped clothing with the appropriate star symbol and a big $\mathrm{N}$ for Niederlande attached. Figure 8.4 shows two of Karel's Buchenwald registration cards, duly signed by himself and the "Häftlings-eigentumverwalter", the camp's custodian of confiscated property.

In Buchenwald the men were put to work building more barracks, or, if they were unlucky, in the quarry. The new Dutch arrivals were treated more harshly than the "regular" inmates. Their condition quickly started to deteriorate due to lack of food, hard labour, cold weather, inadequate clothing and footwear, standing on roll call for up to seven hours and other forms of direct maltreatment. Within a month the first deaths occurred; three months after arrival more than 30 had died. But in the eyes of the Nazis it was not enough, and it took too long. On $22^{\text {nd }}$ May, 341 of the remaining men were transferred to the Mauthausen concentration camp near Linz in Austria, where conditions were even worse. The order for the transfer came from the SS in Berlin, probably from Himmler himself; he had been kept in the loop by Rauter and Seyss-Inquart from the start of the unrest in Amsterdam (H. de Vries, 2000, 2011). The entire deportation process was meticulously recorded, as shown by the selected documents in this chapter. Figure 8.5 shows part of the transfer list from Buchenwald to Mauthausen. This bureaucracy did not last as the number of victims increased. Jews who were not immediately killed in Auschwitz a year later were still registered (and tattooed) when they arrived, and registered again when they died, but not those who went directly to the gas chambers. When deportations to Sobibor started in 1943, nobody bothered anymore with such bureaucratic niceties. There was no need: the process of robbing them from their possessions and their identity had already been completed before they left Westerbork.

KL Mauthausen was operated from $8^{\text {th }}$ August 1938, five months after the $A n$ schluss of Austria. With Gusen, a major sub-camp just 2 km east of Mauthausen, it was classified Lagerstufe-III, the hardest possible regime of all camps (until December 1941, when the death camps in occupied Poland became operational). Reading the detailed description of the bestiality of the SS guards in Buchenwald by Eugen Kogon (1974) and others, it is hard to believe that conditions in Mauthausen were even worse. Karel and Philip arrived in Mauthausen-Gusen around midnight 


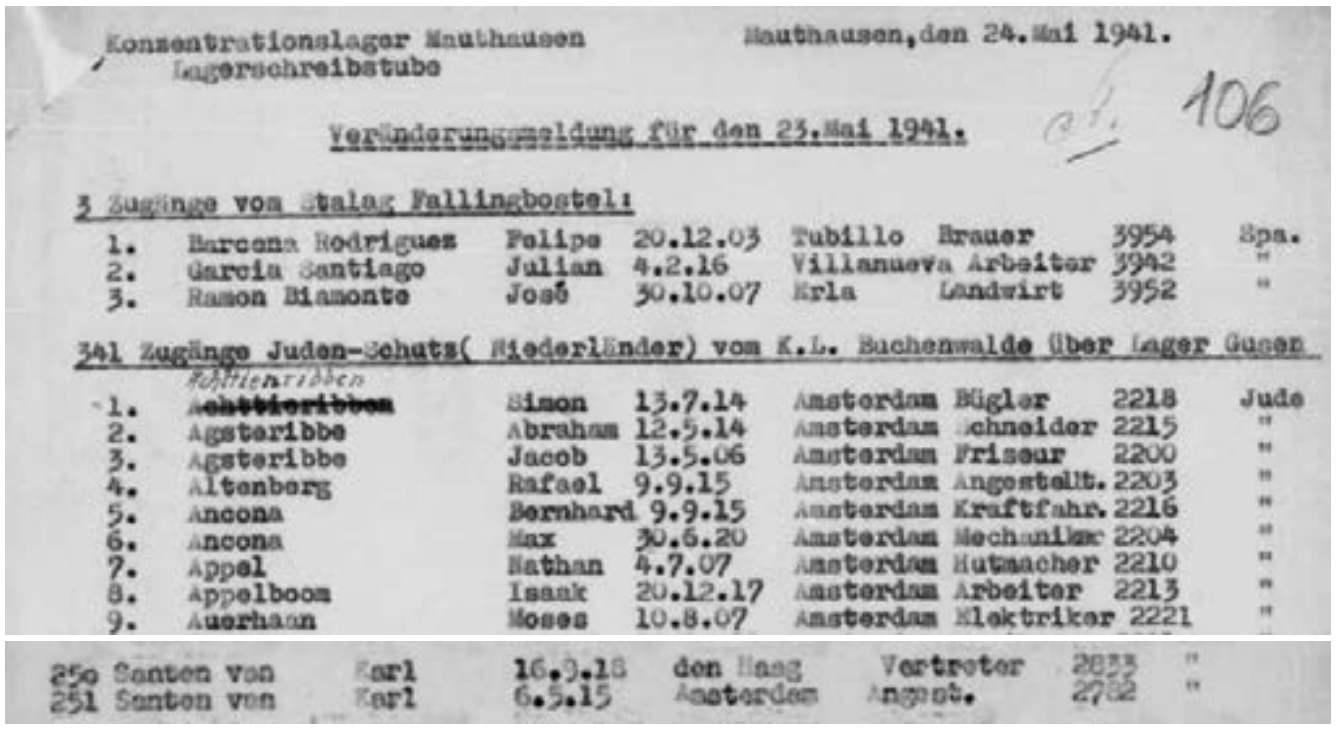

Figure 8.5: The arrival in Mauthausen of 341 Dutch Jews from Buchenwald on $23^{\text {rd }}$ May 1941 as recorded on the following day. The top part of page 1, and below the entries for Karel (no. 250) and Philip (no. 251) on page 6. Philip's full name was Philip Karel; the official listed him also as Karl. Courtesy Gedenkstätte Mauthausen, list AMM/Y/50.

on $22^{\text {nd }} / 23^{\text {rd }}$ May 1941 . Some 50 men were killed that same morning, the others were put to work in the quarry. Mauthausen had the quarry with the infamous staircase, where the prisoners were forced to carry heavy rocks up the 148 steps; Gusen had a quarry as well. The death rate increased dramatically: some were shot "while trying to escape", some were sprayed with ice-cold water to make them sick, some killed themselves. Within four months following their transfer from Buchenwald, most of these men were no longer alive. Their death was duly reported to their next of kin in Holland, and obituaries appeared in the newspapers, and the name Mauthausen as the place of death was not kept secret. This instilled fear in the community: Do not resist, do as you are told, or you will be sent to Mauthausen and to certain death.

According to the entry in the Mauthausen Totenbuch, Karel died on $10^{\text {th }}$ September 1941, at 13.30. Cause of death: "Phlegmone li. K'sch., Allg. Sepsis" (i.e. 'phlegmons on the left patella, general sepsis'). But his death, if he was not killed outright, was due to the conditions in the camp which induced the prisoners to die "from natural causes". Both the cause of death, and the date, may be concocted, such as was the case for his brother Philip (see below), and many others, often to hide the fact that a large group had been killed on the same day (Jacobs, 2000). To the best of our knowledge, Karel was the first one from the erstwhile orphanage children (those who lived there from 1929; list at the back of this book) to be murdered after deportation. Of the 341 Jews from this transport who were 
delivered to Mauthausen not even one survived the unbelievable conditions in this camp. ${ }^{5}$

Philip's death a week before Karel, ostensibly in Mauthausen on $2^{\text {nd }}$ September 1941, was recorded in the Netherlands (Red Cross War Archives, The Hague), probably based on an official death notification sent from Mauthausen. But contrary to Karel, the death of Philip was not recorded in the Totenbücher and both the date and place of death as officially recorded in Holland were false. Documents preserved in the Archives of Mauthausen show that Philip was deported on $11^{\text {th }}$ August 1941 from Mauthausen to the "Lager Sanatorium - Dachau". This was the code name for Schloss Hartheim, a "T4" euthanasia facility some $40 \mathrm{~km}$ east of Mauthausen. He was part of a group of 70 Jewish prisoners, 65 of them Dutch, transported to Schloss Hartheim on $11^{\text {th }}$ August 1941, and duly recorded on a transport list (Fig. 8.6). There were no holding facilities at the castle, and according to the staff of the Mauthausen Memorial all were killed in the gas chamber of Schloss Hartheim the same day.

Following rare public protest ${ }^{6}$ in Germany, Hitler ordered the halting of the $\mathrm{T}_{4}$ programme on $24^{\text {th }}$ August 1941, but the facilities remained in use. Between May 1940 and 1945 some 30,000 people ${ }^{7}$ were killed at Schloss Hartheim in a gas chamber, people with disabilities or mental illnesses, but also increasingly prisoners from Mauthausen, Gusen, and Dachau.

The connection between the $\mathrm{T}_{4}$ programme and the development of the "industrial" killing facilities like Kulmhof (Chelmno), Belzec, Sobibor and Treblinka is well known (e.g. Kogon, 1983). In fact, Christian Wirth, one of worst perpetrators of Aktion Reinhard, was "technical director" of the killings in Schloss Hartheim before he became active in occupied Poland. Franz Stangl, later commandant of Sobibor and Treblinka, also worked in Schloss Hartheim. Step by step the persecution of Jews developed toward genocide during 1941.

Two more trains left Alkmaar (the train station "serving" Camp Schoorl), on $22^{\text {nd }}$ May and $22^{\text {nd }}$ June 1941, bringing the total of deportees to Mauthausen to 1009. Two smaller transports to Mauthausen took place from Enschede and Arnhem in September and October. Fear for Mauthausen was one of the factors which made many Jews in Holland very reluctant to go into hiding, even if they had the opportunity.

5 Two men survived the deportation to Buchenwald, but they were not sent on to Mauthausen (de Vries, 2000, 2011).

6 By people who began to realize that their hospitalized family members, and disabled patients in general, were dying in large numbers.

7 Of which some 23,00o have been recorded in the Hartheim Memorial Book; see also www.schlosshartheim.at/. 


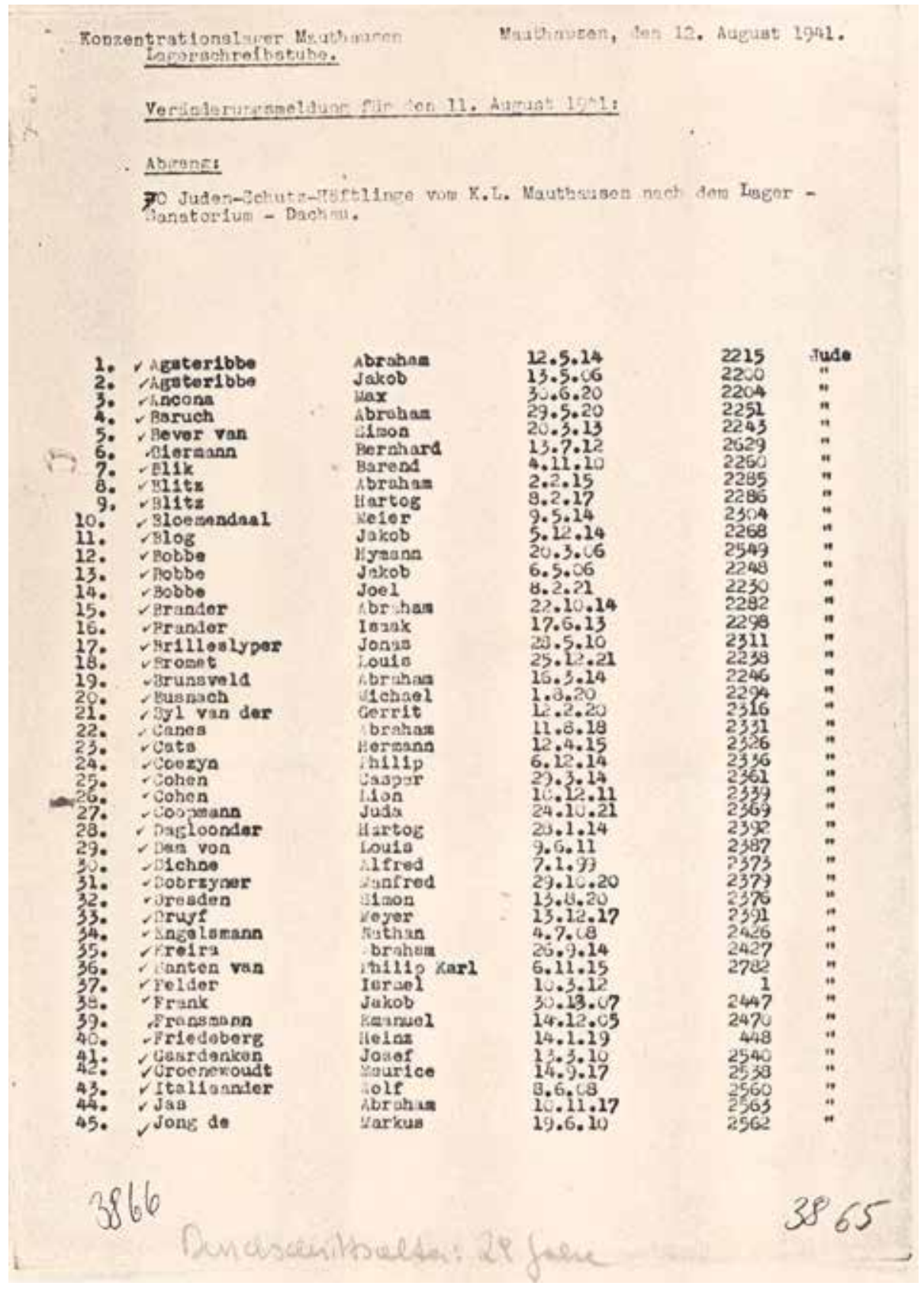

Figure 8.6: "Veränderungsmeldung" (mutation list), dated $12^{\text {th }}$ August 1941, recording the transport of 70 Jews from Mauthausen to Schloss Hartheim, where they were all gassed upon arrival. Philip is listed as no. 37. No. 37 is Israel Felder, with Mauthausen no. 1. He was the first prisoner to arrive in August 1938. Courtesy Gedenkstätte Mauthausen AMM B 15 06-11.8.41. 
Esther (Els) van Santen had left the orphanage in 1939, but she returned on $25^{\text {th }}$ September 1942. She will have heard about the death of her two brothers in September or October, since death notifications were sent back to Holland. It may have been a reason for her to return to the orphanage, thinking she would be safe there. But after receiving a warning, she left the orphanage again on $3{ }^{\text {rd }}$ February, six weeks before its liquidation. She survived the war in onderduik. Els was never keen to talk about her wartime experiences. She died in The Hague on $3^{\text {rd }}$ March 2016. Her sister Jenny (Jansje) survived deportation and emigrated to the USA with her husband. She died in New York on $9^{\text {th }}$ September 1962. The father, David van Santen (Amsterdam, 23 ${ }^{\text {rd }}$ March 1889), also perished in Mauthausen ( $7^{\text {th }}$ October 1943), two years after his sons.

Just two weeks before this book went to press, a comprehensive account about the razzias in Amsterdam, and the fate of the 389 victims was published (de Lang, 2021), just in time to include the reference, but without time to incorporate any new research results in the narrative above.

\subsection{Barend Bora Kool}

Barend Bora was born on $24^{\text {th }}$ August 1927 in Amsterdam. He was brought to the orphanage in Leiden when he was two and a half years old. No stories about him have survived, and he could not be identified on any of the photographs from that period. But his family details, as far as they could be uncovered, ${ }^{8}$ are illustrative for the social circumstances which brought so many children into childcare, despite not being true orphans. Including all the names below is necessary to paint the overall picture.

His mother was Sientje Grootkerk (24 ${ }^{\text {th }}$ May 1886), and his father was Barend Kool $\left(23^{\text {rd }}\right.$ November 1894$)$. His father had two children from a previous marriage ${ }^{9}$ with Leentje Grootkerk (no direct relation of Sientje): Eva (12 ${ }^{\text {th }}$ January 1918) and Mozes $\left(21^{\text {st }}\right.$ March 1944). Sientje also had children, nine in fact, from a previous marriage (in 1907) to Meijer van West, who had died in 1922 at age 41. So Barend Bora had a whole suite of half-brothers and half-sisters. One of them, Adriana van West, also lived in the orphanage in Leiden (from $17^{\text {th }}$ June 1926 to $27^{\text {th }}$ November 1929 ; she left before the arrival of Barend Bora). The father, Barend Kool, died on $16^{\text {th }}$ December 1927, four months after his marriage, 33 years old. Barend Bora was born just under eight months later, so he never knew his father, and he was brought to the orphanage in

8 See https://www.schenk.nl/.

9 The marriage was on $10^{\text {th }}$ January 1917 ; the divorce was on either $25^{\text {th }}$ February or $25^{\text {th }}$ May 1927 (Schenk Genealogie). 


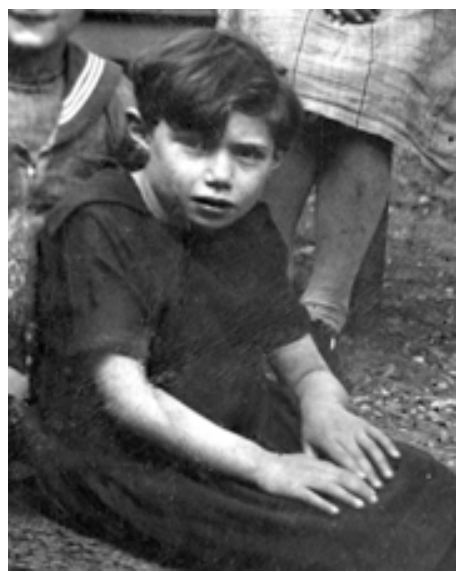

Figure 8.7: Adriana van West, Barend B. Kool's half-sister, at the Langebrug school in Leiden, 1927/1928.

Leiden on $16^{\text {th }}$ January 1931. Circumstances as a widow in an age without comprehensive social welfare will have been difficult for Sientje, but on $25^{\text {th }}$ May 1932, she married for a third time, to Arend van de Kar, a rag merchant. Just five days later, she collected Barend Bora from the orphanage in Leiden, to live with his mother and new stepfather in Rotterdam. The municipal family register (courtesy Roy Schenk, personal communication, October 2018) shows that his other half-siblings, Adriana, Roosje and Schoontje van West, from Sientje's first marriage, also joined their mother and new stepfather. But Barend Bora was obviously not doing well, since he was taken in by Achisomov, the children's ward of the Jewish mental institution Het Apeldoornse Bos (Ch. 1), on $20^{\text {th }}$ January 1936 . He would stay there until the fatal night of $21^{\text {st }} / 22^{\text {nd }}$ January 1943 when all the patients, close to 1000, were lifted from their beds and taken directly from Apeldoorn to Auschwitz (Ch. 7.3).

From all the above-mentioned family members, only Adriana and Rebecca van West survived the war. Barend Bora was fourteen when he was murdered. There is no photograph of him, but his half-sister Adriana van West appears on a photograph at the Langebrug school in Leiden (Fig. 8.7).

\subsection{Jacques Witteboon is deported from France}

Jacques Maurice Witteboon (Fig. 8.8) was born in Amsterdam $26^{\text {th }}$ April 1918, from a second marriage of his father, Salomon (Amsterdam, $6^{\text {th }}$ January 1875). His mother, Marianne Sarphati (Amsterdam, $23^{\text {rd }}$ December 1878 ), had a daughter from a previous marriage. Jacques spent almost nine years in the Leiden orphanage, from 1927 to 1936 . He appears on the group photograph from $193^{2}$ (Fig. 4.14, no. 21). In 1940-1941 he worked as a salesman, living with his mother in Amsterdam.

There is no information available about how Jacques got to be in France in 1942. Was he trying to escape via Spain or Switzerland? Records show that he was deported to Kosel/Auschwitz from Pithiviers. The Pithiviers Camp was one of the first such camps in occupied France. It initially held Jews with non-French nationalities, arrested by the French police on instructions from the Germans or the collaborative French government in Vichy. Children were separated from their parents, who were often deported without them. 
Six transports left Pithiviers between $25^{\text {th }}$ June and $21^{\text {st }}$ September 1942, carrying 6079 people to Auschwitz or Kosel; 4027 were selected for work (2652 men and 1375 women) of which 162 (4\% of those selected, $2.7 \%$ of the total number of deportees) survived (156 men and 6 women). Jacques Witteboon was part of the second transport $\left(17^{\text {th }}\right.$ July 1942), and did not return. Some sources (see the Joods Monument references) suggest that he was killed on $19^{\text {th }}$ July, i.e. upon arrival, but as far as is known, everybody on this transport was selected for work upon arrival. Indeed, the Netherlands Red Cross reported that he was part of the group going through Kosel. His death is reported as $2^{\text {nd }}$ September 1942 in the Auschwitz Sterbebücher (as recorded in his Red Cross dossier).

The Pithiviers Camp is not as well known as the camp at Drancy, which served as the main holding and transfer camp for Jews in France. Between June 1942 and July 1944 some 67,400 Jews were deported in 64 transports from Drancy to the extermination camps in the East. Only 1542 (2.3\%) were still alive in 1945 .

\subsection{Alexander Lipschits is caught in Belgium $^{10}$}

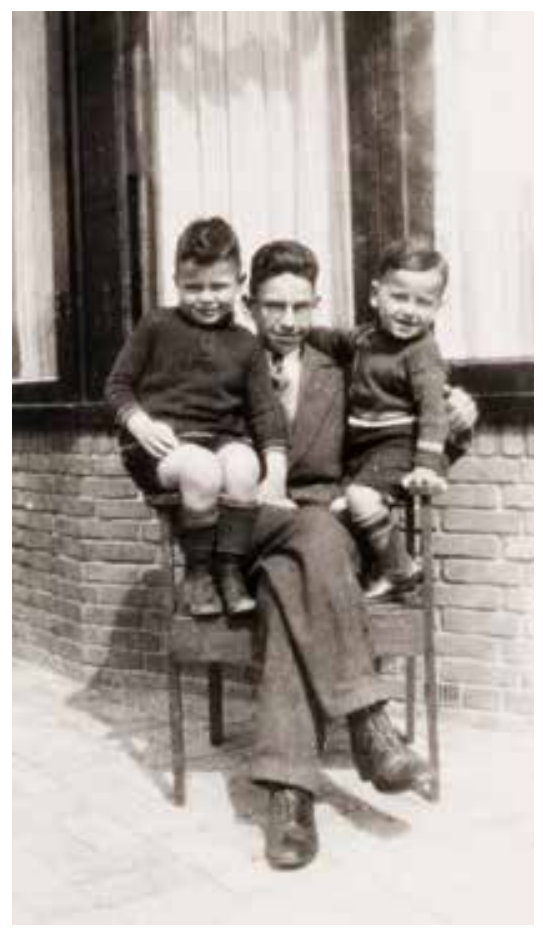

Figure 8.8: "Jack (Jacques) Witteboon with Dikky and Semmy" in front of the annex, 1936. (Comment attached to original photo as donated to the Joods Historisch Museum. Dikky is Herman Rozeveld, Semmie is Willem van Weddingen.) Photo F1635-1, courtesy Jewish Historical Museum Amsterdam.

Alexander was born in Bergen op Zoom, Netherlands, on $24^{\text {th }}$ August 1926; he entered the orphanage on $15^{\text {th }}$ May 1930 when he was three years old and left again on $13^{\text {th }}$ October when he was four.

His father was Mozes ("Max") Lipschits (Maastricht, $23^{\text {rd }}$ July 1901), and his mother was Marianne Walvis (Rotterdam, $4{ }^{\text {th }}$ October 1899). His parents were registered by the Belgian alien police in 1924 but must have returned to the Netherlands, since Alexander was born there, and the family was later registered in Breda

10 This chapter was made possible by the exceptional assistance given to the author by the staff of the State Archives of Belgium in Brussels (ARA) and Kazerne Dossin (Mechelen/Malines): Mrs. Alexandra Matagne, Mr. Felix Strubbe and Mrs. Laurence Schram. I also thank Mr. Ron Bosten who provided the photographs. 


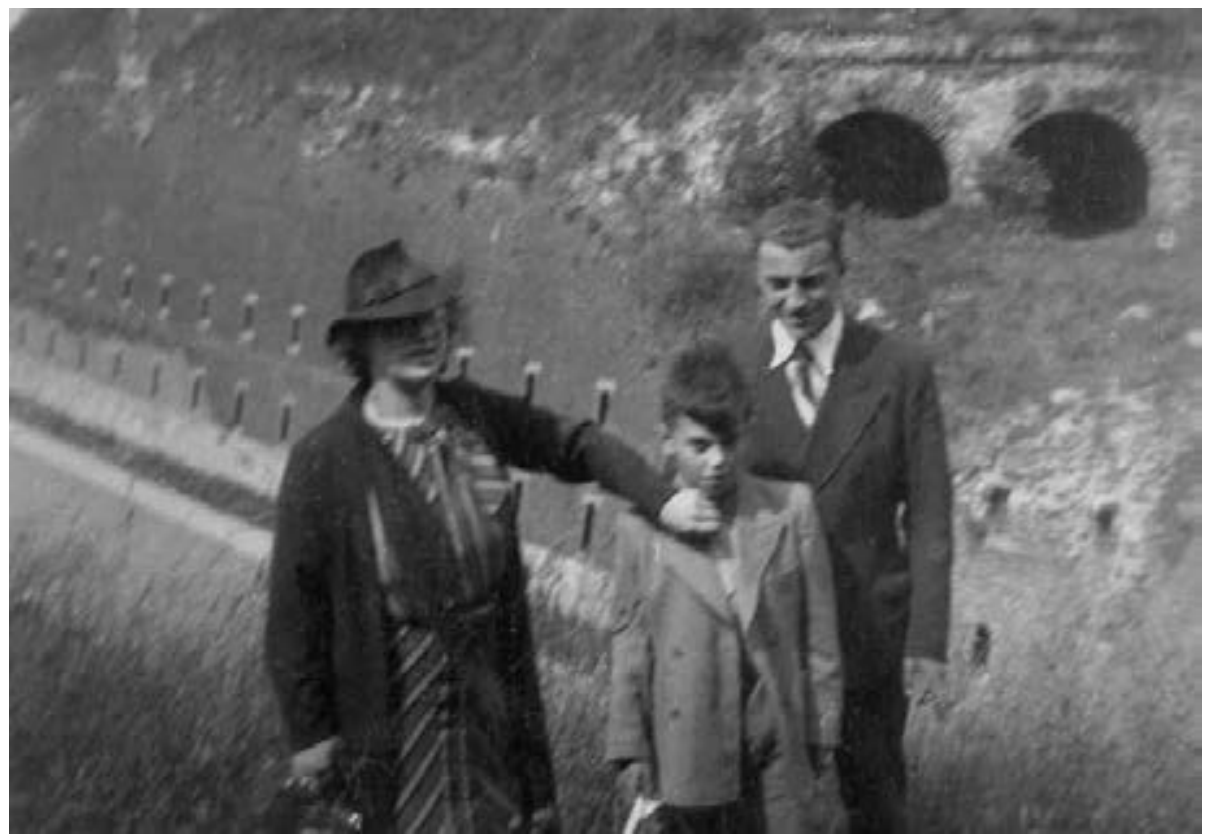

Figure 8.9: Alexander Lipschits with his mother, Marianne Walvis, and his uncle, Levie (Louis) Walvis, c. 1937. Note in the background two entrances to the Maastricht cave system. Photo courtesy R. Bosten, grandson of Louis Walvis.

and Maastricht. Other members of the Lipschits family also had close ties with Maastricht as well as with Antwerp.

The circumstances which brought Alexander to the orphanage are not known. The choice for Leiden was most likely determined by his young age. He was reunited with his parents later that year. When war broke out, the family lived in Maastricht, close to the St Pietersberg, a prominent hill penetrated by countless tunnels and caves as a result of mining the Cretaceous limestone (Fig. 8.9). In the spring of 1942, even before deportations from Westerbork had started, they were preparing to go into hiding in Belgium. The family of Uncle Louis Walvis (Fig. 8.9), who survived the war, thinks that they escaped to Belgium through the above-mentioned cave and tunnel system, together with Abraham Levie, who had lived in their house in Maastricht, and who, it seems, provided the hiding address in Brussels.

They managed to obtain fake Belgian identity cards (Figs. 8.10 and 8.11), ostensibly issued by the municipal authorities in Wetteren, a small community near Ghent in Belgian Flanders. The ID card for Max ("Hendrik Willems") is dated $5^{\text {th }}$ May 1942, for his wife, Marianne ("Maria van Dam"), $5^{\text {th }}$ July, and for Alexander ("Jan Willems") and their friend Abraham Levie ("Johan Wouters"), 8 $8^{\text {th }}$ July 1942. 
From November 1941 (re-enforced on $5^{\text {th }}$ June 1942), Jews in the Netherlands were no longer allowed to move to another address without a special permit. The move of the Lipschits family was therefore "illegal" and they were duly recorded as fugitives, together with Abraham Levie (Algemeen Politieblad, no. $37,17^{\text {th }}$ September 1942,1044 , notice 1931).

After living in hiding for some ten months, the family was arrested. Relatives of the family think that Abraham Levie was arrested first, when he could not resist the temptation to go out on the streets of Brussels, but the sequence of events, and the remarkable number of documents which have been preserved, may not support this assumption. On $25^{\text {th }}$ May 1943 , the Lipschits family was brought to Kazerne Dossin in Mechelen (Malines), which served as the main holding and transit place (Fig. 8.12) for Jews being deported from Belgium. Abraham Levie was brought to Kazerne Dossin much later, on $6^{\text {th }}$ April 1944. He was deported to Aus-

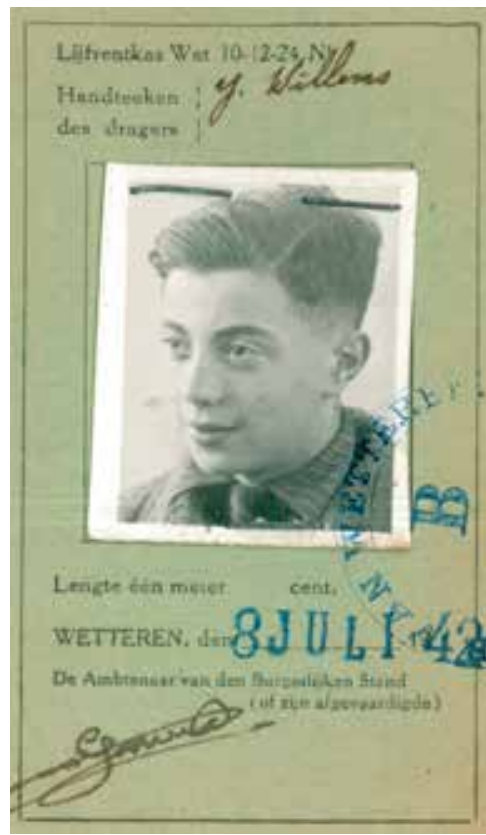

Figure 8.10: Alexander Lipschits in 1942, from his counterfeit identity card in the name of Jan Willems. The fake ID of his father is shown in full in Figure 8.11 because it shows remarks added by the SD after their arrest. Photo courtesy Archief Oorlogsslachtoffers (AOS), Brussels. chwitz with Transport XXV on $19^{\text {th }}$ May 1944. The Lipschits family was arrested on $24^{\text {th }}$ May 1943 , or maybe the day before. The German police added the date to their comments on the fake ID card of Mozes, after their arrest (Fig. 8.11).

Unlike Camp Westerbork, which was situated in the middle of nowhere, close to the border with Germany, and out of sight of most people in Holland, Kazerne Dossin is situated in the medieval city of Mechelen, on the banks of the Dijle River. Prisoners were delivered by truck (Fig. 8.12), and a convenient spur line connected the barracks to the national railway network of Belgium. It fitted the German plans to "solve their so-called Jewish problem" (Schram, 2018). Between August 1942 and August 1944, 25,274 Jews were deported to Auschwitz, with only 1218 survivors (4.8\%). The transports (ibidem) also deported 354 Zigeuner (“Gypsies": 33 survivors, 9.3\%) and 218 "special cases" (144 survivors, 66\%).

The names of the deportees were recorded on 28 administrative transport lists, numbered I to XXVI, with list XXII split into A and B, and one list numbered Z2 ( $\mathrm{Z}$ for Zigeuner), corresponding to 22 actual train transports. The Lipschits family was entered on the list of Transport XXI as numbers 336, 337 and 338 (Fig. 8.13). The date in the upper-left corner, $25^{\text {th }}$ May 1943 does not refer to the departure 


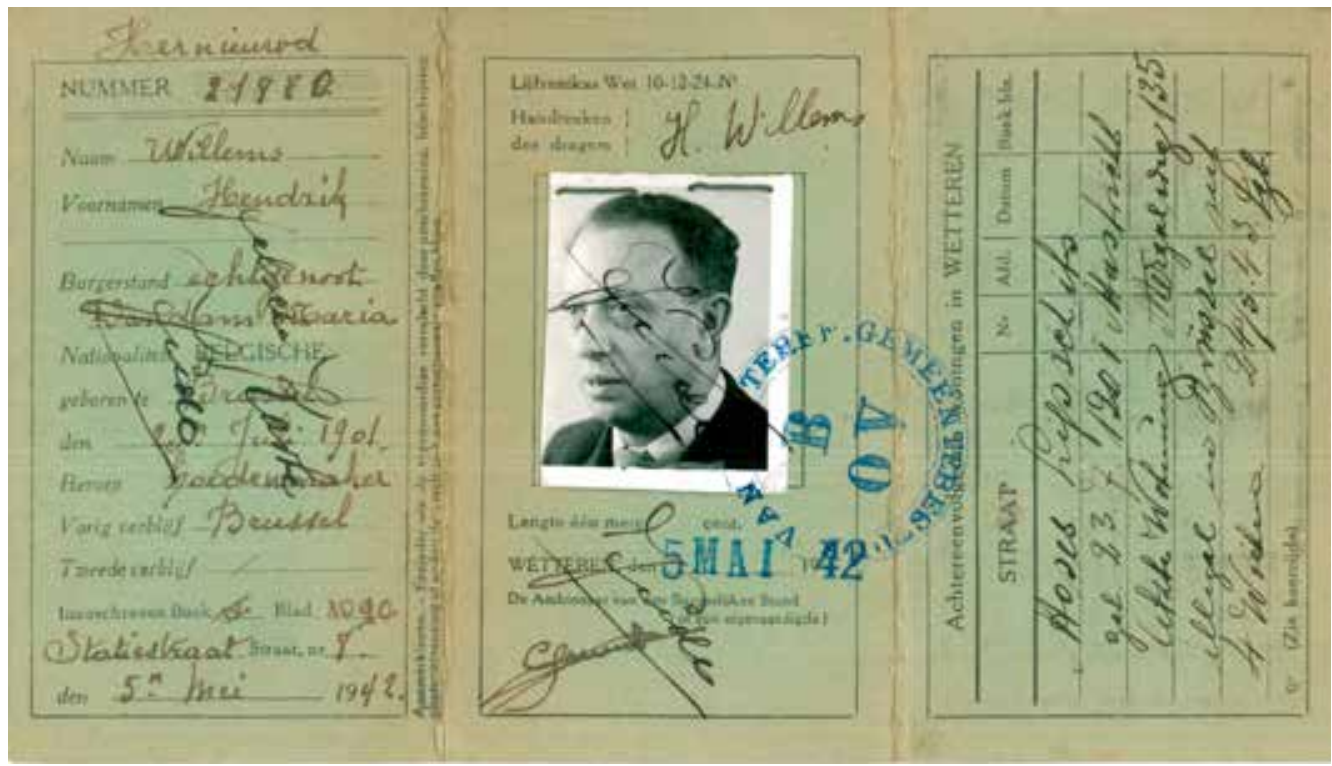

Figure 8.11: The counterfeit Belgian ID card of Mozes Lipschits, Alexander's father, including remarks added by the German police after their arrest. On the left-hand part of the card, obliquely across the original text, he wrote "falsche Karte" (counterfeit document), and below that "Jude" (Jew). Across the middle part again "Jude" across the photograph and again below it. On the right-hand part of card, intended to keep track of address changes, he added Max's real name, date and place of birth, and his last address in Maastricht: Mergelweg 135, and the remark "illegal in Brüssel seit 4 Wochen" ("illegally in Brussels for four weeks"), and the date, $24^{\text {th }}$ May 1943. Finally, unreadable, are his initials? Photo courtesy Archief Oorlogsslachtoffers (AOS), Brussels.

of this transport; it is the date on which the people on this page were registered in Kazerne Dossin. Transport XXI left on $31^{\text {st }}$ July 1943, the seventeenth train from Dossin. It carried $155^{2}$ Jews to Auschwitz, of which 21 survived. Alexander and his parents were probably killed upon arrival in Auschwitz on or around $2^{\text {nd }}$ August 1943. The Lipschits family was locked up in Kazerne Dossin for more than two months before their transport left on $3{ }^{\text {st }}$ July. Most people who entered Dossin in 1943 had to wait there one to three months before being deported. The previous year, during the month of September 1942, four trains left Dossin, carrying 6790 Jews to Auschwitz. During October three trains took away 4842 people. But then the deportations slowed down with "only" one train in January, April, July and September, an astounding difference with the deportations out of Westerbork.

By early 1943, the Sicherheitsdienst (SD) had difficulties in meeting its target number of Belgian Jews caught and ready to be deported. And that target was not as "ambitious" as it was in Holland to begin with. Many more Jews in Belgium survived the war $(60 \%)$ than did in the Netherlands $(25 \%)$. This has led commentators to wonder if the level of anti-Semitism and active local collaboration with the Germans has been significantly higher in Holland as compared to Belgium or France. But 


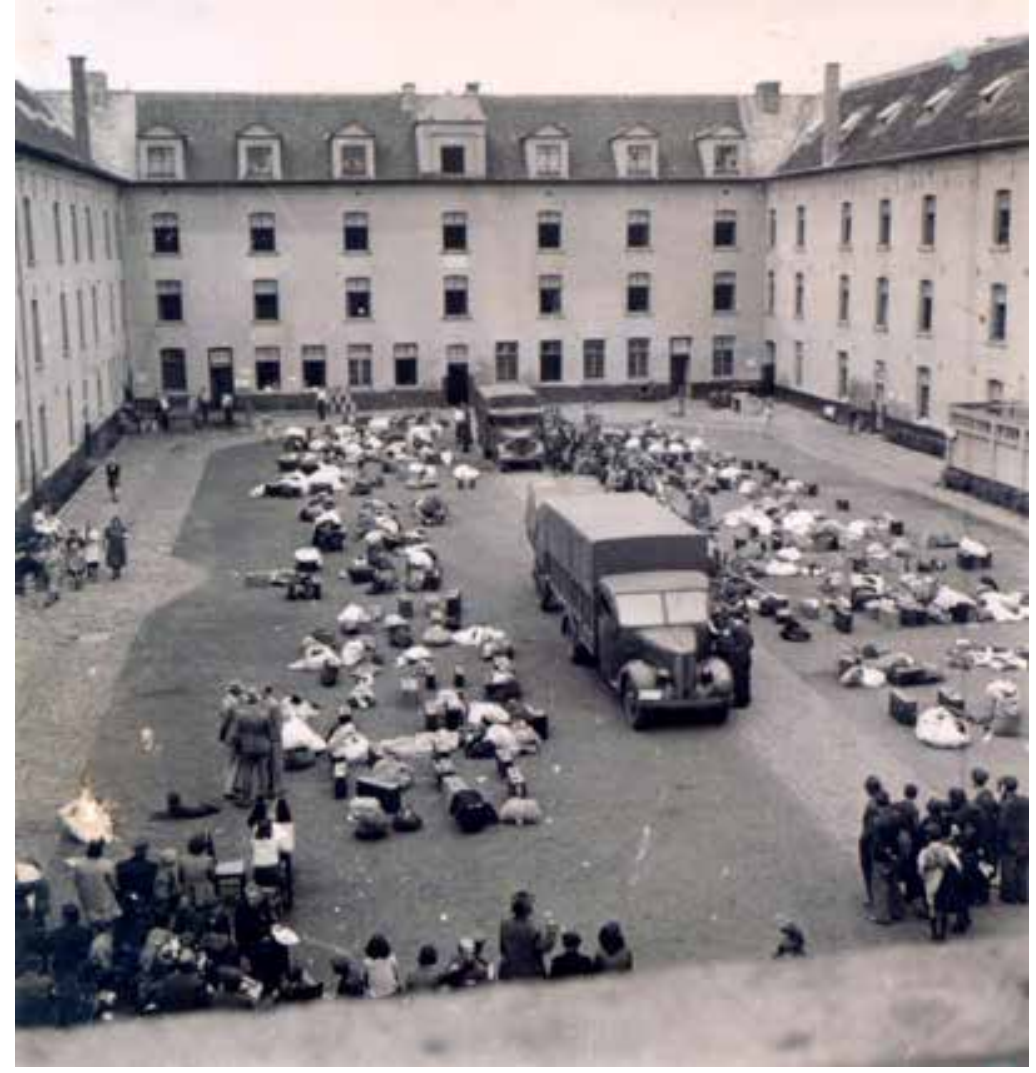

Figure 8.12: Arrested Jews waiting in the courtyard of Kazerne Dossin in Mechelen, Belgium, 1942. JMVD Fonds Kummer.

there seems to be no evidence for any such claims. Anti-Semitic riots in Antwerp and Brussels in 1939 and early 1940 had no significant equivalent in the Netherlands, and Kazerne Dossin has dedicated much effort in highlighting the collaborative role of city mayors, civil servants, police, etc., which seems to have been as common there as it was in the Netherlands.

In Holland, until the arrival of refugees in 1933, the vast majority of Jews had Dutch citizenship. They were duly recorded by the Civil Registry as belonging to the Jewish faith just like Catholics and Protestants (Ch. 1), and it was very easy for the Germans to complete their inventory of who was Jewish and where they lived. Because they had already been registered before the war, not complying with Decree 6/1941 would have made little difference.

In Belgium however, more than $95 \%$ of the Jews were aliens, with German or Polish nationalities, or without nationality papers at all. Moreover, registering people's faith was unconstitutional in Belgium, and the Germans needed two 


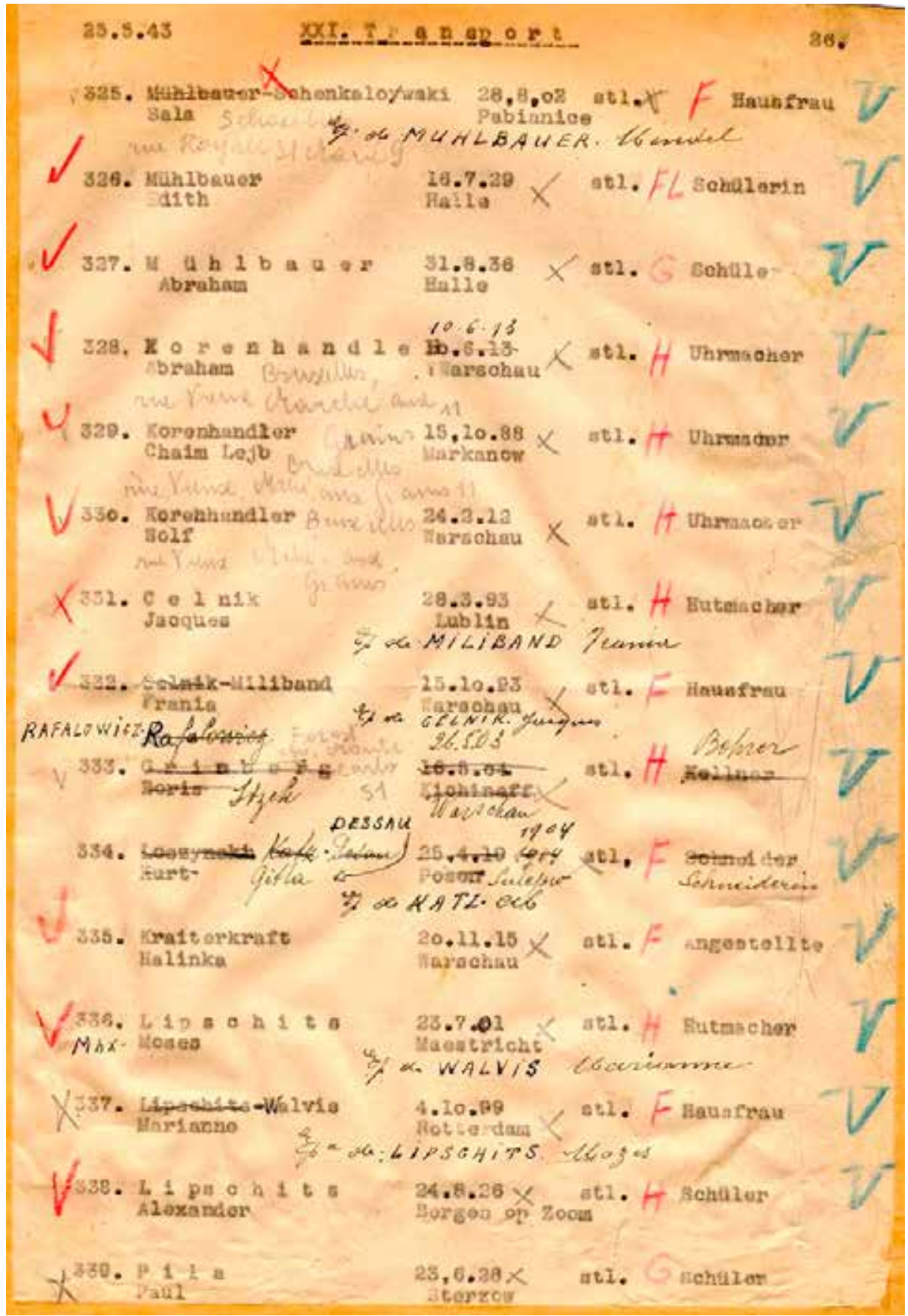

Figure 8.13: The page of the list for Transport XXI showing Alexander Lipschits and his parents (see text). Note that the date in the upper-left corner indicates the arrival date in Dossin, not the date of the transport, which left on $31^{\text {st }}$ July 1943. Courtesy Kazerne Dossin and AOS, Brussels. 
public exercises instructing Jews to register themselves as Jews (Schram, 2018). There were some 90,00o Jews living in Belgium in 1940, and some 45,000 of them did not comply with the order to register themselves, a significant difference with the situation in the Netherlands. The fact that about the same number did comply may be equally significant.

The level of suspicion in Belgium, having been the victim of a previous brutal German occupation just 25 years earlier, was much higher than in Holland, and resistance developed earlier. Some people managed to escape from the Belgian train transports, and one transport was even stopped by three young men from Ukkel to let the deportees escape (Schram, 2018). Belgium was administered by the Wehrmacht, whereas in Holland the German civil administration, run by four fanatic Austrian Nazis, had a free hand from May 1940.

This book is not the place to discuss the significant differences in survival rates between the Netherlands (27\%), Belgium (47\%), and France (75\%), but the abovementioned factors suggest that one must be careful before drawing conclusions from the bare numbers. For a comprehensive treatment of the Holocaust in the three countries, the reader is referred to Griffioen and Zeller (2010).

\subsection{So many more - the family of Sally Montezinos}

All 168 children on the list at the end of this book had family: one or even two parents, siblings, uncles, and so on. Many, like Barend Bora Kool (Ch. 8.2) or Barend and Salomon Ritmeester, had extended families. Inevitably, during the investigations it was discovered what happened to these family members.

Table 8.1 lists the family of Sally Montezinos, who, as told in Chapter 7.2 and 7.4, preferred to stay with his orphanage friends rather than join his "real" family, as it was in 1941. Sally's father had died before the war. His mother, Louise Hagenaar, had nine children, six children-in-law, and four grandchildren. The table only includes Sally and his direct family, in total 20 people, without his uncles, aunts or cousins.

They lived in The Hague, Leiden, Amsterdam, Apeldoorn, and other places. It did not make a difference where they were: they were all caught up in the persecution and deported with nine different transports between August 1942 and July 1943. Not one of them survived.

Such was the effectiveness of the Holocaust in the Netherlands.

Surely, there were photographs of these family members, albums for the grandchildren, or stacked in boxes. Despite the long-standing efforts of the Westerbork Memorial Museum, the Joods Monument, and individual authors 
Table 8.1 The family of Sally's mother: Louise Montezinos-Hagenaar, her children and grand-children

Mother:

\begin{tabular}{|c|c|c|c|}
\hline \multicolumn{2}{|c|}{ Louise Hagenaar } & b 11-01-1887 & d 23-04-1943 Sobibor \\
\hline & Children: & & \\
\hline \multirow[t]{3}{*}{1.} & Branca & b 01-10-1909 & d 09-07-1943 Sobibor \\
\hline & - C. Hakker & b 21-01-1912 & d 09-07-1943 Sobibor \\
\hline & - Lea & b 19-12-1935 & d 09-07-1943 Sobibor \\
\hline \multirow[t]{3}{*}{2.} & Jacob & b 27-03-1911 & d 13-03-1943 Sobibor \\
\hline & - J. Elburg & b 04-05-1910 & d 13-03-1943 Sobibor \\
\hline & - Louise Jeanne & b 06-11-1937 & d 13-03-1943 Sobibor \\
\hline \multirow[t]{2}{*}{3.} & Grietje & b 21-09-1912 & d 30-09-1942 Auschwitz \\
\hline & D. Agsteribbe & b 31-01-1911 & d 09-10-1942 Auschwitz \\
\hline 4. & Anna & b 05-01-1914 & d 13-03-1943 Sobibor \\
\hline \multirow[t]{3}{*}{5.} & Bilha & b 11-04-1916 & d 11-12-1942 Auschwitz \\
\hline & - Sal. Levij & b 26-05-1916 & d 28-02-1943 Auschwitz \\
\hline & - Alida & b 06-02-1941 & d 11-12-1942 Auschwitz \\
\hline \multirow[t]{3}{*}{6.} & Eva & b 30-08-1917 & d 26-08-1942 Auschwitz \\
\hline & - L.Tokkie & b 06-09-1913 & d 30-09-1942 Auschwitz \\
\hline & - Bettie & b 01-04-1939 & d 26-08-1942 Auschwitz \\
\hline \multirow[t]{2}{*}{7.} & Abraham & b 23-08-1919 & d 31-01-1943 Auschwitz \\
\hline & - L. Cohen & b 20-01-1916 & d 01-10-1942 Auschwitz \\
\hline 8. & Josephina & b 17-05-1922 & d 13-03-1943 Sobibor \\
\hline 9. & Sally & b 06-05-1924 & d 04-11-1943 Dorohucza* \\
\hline
\end{tabular}

* Official date. Both date and place of Sally's death are uncertain. He will most likely not have survived the liquidation on $8^{\text {th }}$ November 1943 of Dorohucza and the other satellite camps of Sobibor.

to "add a face" to the names of the victims, not a single photograph has (yet) come to light for any of Sally's nineteen family members. Sally is the only one of the entire family of whom photographs exist, all taken during his sixteen-year stay in the orphanage. On $6^{\text {th }}$ September $2011,{ }^{11}$ a notice appeared on the Joods Monument that several members of the family were entitled to payments out of a life insurance, and asking relatives, however remote, to come forward. But there is no one left to make a claim. When this book went to press, the notice was still there.

By December 2020, the Joods Monument showed only two of the nineteen family members on the page "family of Louise Montezinos-Hagenaar"12 with the comment

11 Possibly the notice has already been posted in earlier years.

12 https://www.joodsmonument.nl/nl/page/144387/louise-montezinos-hagenaar. To be precise: The other family members are individually included on the Joods Monument, but the memory that they belonged to one family was not yet recognized. 
"(as yet) no other family members are known". It is in no way criticism about the Joods Monument. On the contrary: it shows how frighteningly close the Nazis came to not only eradicate entire families, but even destroy the evidence, the memory, that they ever existed.

It seems to be a miracle that there were any survivors at all. Maybe it is. The survivors who contributed so much to the stories in this book are mentioned in the previous chapters. The following chapter presents nine survivor stories in more detail.

\section{References}

Griffioen, P. \& R. Zeller, 2011; "Jodenvervolging in Nederland, Frankrijk en België, 19401945. Overeenkomsten, verschillen, oorzaken". Amsterdam, Boom, ISBN 0789085068112. [Comparison of Jewish victimization rates in the Netherlands, Belgium and France.] An English summary of the dissertation which preceded (2008) the book is available from the University of Amsterdam at https://pure.uva.nl/ws/files/4255606/58120_12. pdf. See also P. Griffioen \& R. Zeller, 20o6; "Anti-Jewish policy and organization of the deportations in France and the Netherlands, 1940-1944: A comparative study", Holocaust and Genocide Studies 20 (3), 437-473, and a similar comparative study with respect to Belgium: P. Griffioen \& R. Zeller, 1998; "The persecution of the Jews: Comparing Belgium and the Netherlands", NetherlandsJ. Social Sciences 34 (2), 126-164.

Jacobs, Luise, 2000; "De verborgen massamoorden in Schloss Hartheim”. In: Keulen-Woudstra, 200o, pp. 31-42. [Relevant to understand the false death details of Philip van Santen (Ch. 8.1) recorded in Holland.]

Jong, L. de, 1969-1994; “Het Koninkrijk der Nederlanden in de Tweede Wereldoorlog”. http:// www.dbnl.org or http://www.loedejongdigitaal.nl/. [The standard (contemporary) history of the Netherlands during the war. The entire text is available online (with search facility). For more recent interpretations, see Blom et al., 2021.]

Kogon, Eugen, 1974; “Der SS-Staat. Das System der deutschen Konzentrationslager”. München, Kindler Verlag. [Kogon was a Christian opponent to the Nazi regime who survived 6 years in Buchenwald.]. Dutch edition: Kogon, Eugen, 1976; "De SS-staat". Amsterdam, Amsterdam Boek, no ISBN. English and Dutch translations exist in several editions.

Kogon, Eugen, 1983; "Nationalsozialistische Massentötungen durch Giftgas. Eine Documentation". Frankfurt a/M, S. Fischer Verlag, ISBN 3100404025.

Lang, Wally de, 2021; “De razzia's van 22 en 23 februari 1941 in Amsterdam. Het lot van 389 Joodse mannen”. Amsterdam, Uitgeverij Atlas Contact, ISBN 9789045042749. [This first comprehensive account of the razzias which preceded the February Strike, and the fate of the deportees to Buchenwald and Mauthausen was published just before the present book went to press.] 
Schram, Laurence, 2018; "Dossin. Wachtkamer van Auschwitz". Tielt, Lannoo, ISBN 9782390250395. [One of the first comprehensive studies about the transit camp Kazerne Dossin in Mechelen (Belgium), through which 25,484 Jews and $35^{2}$ Roma and Sinti were deported to Auschwitz, including Alexander Lipschitz and his family. Only 1222 survived the deportations.]

Vries, Hans de, 2000; "Sie starben wie Fliegen im Herbst". In: Keulen-Woudstra, A.B. van, 2000, "Mauthausen, 1938-1998". Utrecht, Van Gruting, ISBN 9075879067, pp. 7-18.

Vries, Hans de, 2011; "Mauthausen. Een geval apart". https://pure.knaw.nl/ws/f1les/6338408/2011 and search for Vries_MauthausenEenGevalApart.pdf. [In Dutch, summarizing the special significance of Mauthausen in Dutch wartime history.] 